\title{
Influence of phytate and phytase on performance, bone, and blood parameters of broilers at $\mathbf{4 2}$ days old
}

\author{
J. Broch" ${ }^{1 \#}$, V.D.L. Savaris', L. Wachholz', E.H. Cirilo', G.L.S. Tesser ${ }^{1}$, W.J. Pacheco ${ }^{2}$, C. \\ Eyng $^{1}$, G.M. Pesti ${ }^{3}$ \& R.V. Nunes ${ }^{1}$ \\ ${ }^{1}$ Department of Agricultural Sciences, Western Parana State University, Marechal Cândido Rondon PR, Brazil \\ ${ }^{2}$ Department of Poultry Science, Auburn University, Auburn, Alabama USA \\ ${ }^{3}$ Department of Poultry Science, University of Georgia, Athens, Georgia USA
}

(Submitted 14 February 2020; Accepted 15 January 2020; Published 23 February 2021)

\author{
Copyright resides with the authors in terms of the Creative Commons Attribution 4.0 South African Licence. \\ See: http://creativecommons.org/licenses/by/4.0/za \\ Condition of use: The user may copy, distribute, transmit and adapt the work, but must recognize the authors and the South African \\ Journal of Animal Science.
}

\begin{abstract}
The objective was to evaluate the effect of diets containing various levels of phytate and phytase on broilers from 1 to 42 days old. The treatments consisted of a combination of diets containing high (HP), medium (MP) and low (LP) phytate with positive control diet (PC) and a negative control diet (NC) that was similar to the PC in energy and protein but with less calcium and phosphorus. Three additional diets, based on the NC were supplemented with 500,1000 , or $1500 \mathrm{FTU} \mathrm{kg}^{-1}$ of phytase. Broilers that received the NC diet exhibited the lowest weight gain (WG), whereas those supplemented with $1000 \mathrm{FTU} \mathrm{kg}{ }^{-1}$ obtained $2.84 \%$ higher WG compared with PC. Broilers that received NC had the lowest breaking strength and dry matter. Birds fed HP diets that received NC and NC $+500 \mathrm{FTU} \mathrm{kg}^{-1}$ had a higher concentration of serum Ca and $\mathrm{P}$ than birds fed LP diets. Broilers fed the NC and NC + 500 and $1000 \mathrm{FTU} \mathrm{kg}^{-1}$ had lower tibia Ca levels compared with birds fed the PC. Broilers fed HP diets had higher tibia Ca content than MP. Phytase supplementation had a positive response in diets with reduced $\mathrm{Ca}$ and $\mathrm{P}$. Based on regression analysis the optimum inclusion of phytase to improve broiler performance parameters was calculated as $952 \mathrm{FTU}^{\mathrm{k}}{ }^{-1}$.
\end{abstract}

Keywords: broiler nutrition, feedstuffs, poultry production, phosphorus, tibiae

\#Corresponding Author: brochjomara@yahoo.com.br

\section{Introduction}

Phytic acid is the principal storage form of phosphorus $(P)$ in cereal grains and legumes. Phosphorus can be found in plant material as a mixed salt, known as phytate, which represents $50-85 \%$ of the total $\mathrm{P}$ content in plant seeds (Pallauf \& Rimbach, 1997; Cowieson et al., 2016).

Phytate has low solubility in the small intestine, it is poorly absorbed by broilers, and its negative charge makes it a potent mineral chelator that forms insoluble salts with minerals. Also, phytate can reduce the digestibility of protein and energy (Wilkinson et al., 2014). Poultry diets are composed mainly of corn and soybean meal, in which almost $70 \%$ of $P$ is in phytate form. Broiler diets contain about 2.5 to $4.0 \mathrm{~g} \mathrm{~kg}^{-1}$ of phytate (Ravindran, 1995).

Phytase enzymes are capable of initiating phytate dephosphorylation by generating a series of lower myo-inositol phosphate esters through a succession of dephosphorylation reactions to produce inositol and six inorganic P radicals (Selle \& Ravindran, 2007). However, the effectiveness of the enzyme is influenced by the characteristics of the birds (species, age, physiological conditions), dietary factors such as phytate concentration and source, concentration of minerals, and the origin and level of phytase added to the diet (Dersjant-Li et al., 2015).

Phytate utilization may vary between diets, and is dependent on the ingredients, mineral concentrations, protein content, and solubility of the phytate. Gastrointestinal pH influences phytate susceptibility because the addition of hydrogen ions to the phosphate groups of phytate makes it susceptible to the phytase effects (Maenz et al., 1999). The efficiency of phytate $P$ use can also be influenced by genetics. Modern broilers show rapid growth, consume more feed, and have a higher rate of passage than older broiler breeds, which may interfere with the use of phytate $\mathrm{P}$ and may contribute to the inability of commercial chickens to dephosphorylate phytate P efficiently (Zhang et al., 2003). 
The benefits of supplementing a high dose of phytase have been reported in several studies. Gautier et al. (2018) reported increased degradation of myo-inositol hexakisphosphate and increased ileal inositol concentration in response to phytase supplementation. Leyva-Jimenez et al. (2019) reported an improvement in broiler performance, bone mineralization and ileal digestibility of energy from 1 to 24 days old. Walters et al. (2019) demonstrated that rising levels of phytase increased feed consumption and BW, and yielded higher nutrient digestibility and bone mineralization. The benefits have also been observed in laying hen diets with improvement in protein and energy digestibility, increase in egg production, and improvement in eggshell quality (Saleh, 2017). Thus, this study was designed to evaluate the effects of high, medium, and low levels of phytase supplementation performance, bone characteristics, blood parameters, and processing yield of broilers from 1 to 42 days old.

\section{Materials and Methods}

The Western Paraná State University Ethical Review Committee approved all experimental procedures and birds were handled with care to avoid unnecessary discomfort.

Male Cobb 500 broilers chicks $(n=2625)$ were obtained from a commercial hatchery on the day of hatch. Chicks were stratified by weight and randomly distributed in a $3 \times 5$ factorial design that consisted of 15 dietary treatments, with each treatment containing seven replicates of 25 birds per experimental unit. Details of the dietary ingredients for days 1 to 21 (the starter phase) and days 22 to 42 (the grower phase) are presented in Tables 1 and 2.

Table 1 Composition of experimental rations that vary in level of phytate and in the amount of calcium and phosphorus for feeding broilers during the starter phase

\begin{tabular}{|c|c|c|c|c|c|c|}
\hline \multirow{2}{*}{ Ingredients ( $\left.\mathrm{g} \mathrm{kg}^{-1}\right)$} & \multicolumn{2}{|c|}{ HP } & \multicolumn{2}{|c|}{ MP } & \multicolumn{2}{|c|}{ LP } \\
\hline & PC & NC & PC & NC & PC & NC \\
\hline Corn & 539.0 & 553.5 & 577.3 & 590.9 & 610.0 & 624.5 \\
\hline Soybean meal (45\%) & 335.9 & 333.4 & 282.2 & 280.2 & 287.1 & 284.6 \\
\hline Gluten feed meal & 20.0 & 20.0 & 20.0 & 20.0 & 20.0 & 20.0 \\
\hline Wheat bran & 30.0 & 30.0 & 30.0 & 30.0 & - & - \\
\hline Soybean oil & 31.1 & 26.2 & 17.7 & 13.1 & 10.1 & 05.2 \\
\hline Meat \& bone meal & - & - & 20.0 & 20.0 & 20.0 & 20.0 \\
\hline Poultry by-product meal & - & - & 18.5 & 18.5 & 18.5 & 18.5 \\
\hline Monocalcium phosphate & 15.44 & 7.77 & 7.71 & 0.04 & 8.1 & 0.39 \\
\hline Limestone & 11.70 & 11.85 & 8.01 & 8.17 & 7.9 & 8.03 \\
\hline Lysine (51.7\%) & 4.50 & 4.57 & 5.63 & 5.66 & 5.53 & 5.60 \\
\hline Salt & 3.31 & 3.30 & 2.82 & 2.81 & 2.81 & 2.81 \\
\hline DL-Methionine (98\%) & 2.96 & 2.94 & 3.10 & 3.08 & 3.07 & 3.06 \\
\hline Vitamin premix $^{1}$ & 1.50 & 1.50 & 1.50 & 1.50 & 1.50 & 1.50 \\
\hline Sodium bicarbonate & 1.50 & 1.50 & 1.50 & 1.50 & 1.50 & 1.50 \\
\hline L-Threonine (99\%) & 0.82 & 0.82 & 1.16 & 1.15 & 1.10 & 1.11 \\
\hline Choline chloride & 0.60 & 0.60 & 0.60 & 0.60 & 0.60 & 0.60 \\
\hline Salinomycin $12 \%$ & 0.55 & 0.55 & 0.55 & 0.55 & 0.55 & 0.55 \\
\hline L-Valine (99\%) & 0.38 & 0.38 & 0.67 & 0.65 & 0.63 & 0.64 \\
\hline Mineral premix ${ }^{2}$ & 0.50 & 0.50 & 0.50 & 0.50 & 0.50 & 0.50 \\
\hline L-Isoleucine (99\%) & - & - & 0.36 & 0.38 & 0.29 & 0.31 \\
\hline Avilamycin $10 \%$ & 0.05 & 0.05 & 0.05 & 0.05 & 0.05 & 0.05 \\
\hline Inert (sand) & - & 0.40 & - & 0.40 & - & 0.40 \\
\hline
\end{tabular}

PC: positive control; NC: negative control; HP: high phytate; MP: medium phytate; LP: low phytate

${ }^{1}$ Vitamin $A: 2.7 \mathrm{~g}$, vitamin $\mathrm{D}_{3}: 0.75 \mathrm{~g}$, vitamin $\mathrm{E}: 0.06 \mathrm{~g}$, vitamin $\mathrm{K}_{3}: 2.5 \mathrm{~g}$, vitamin $\mathrm{B}_{1}: 1.5 \mathrm{mg}$, vitamin $\mathrm{B}_{2}: 6 \mathrm{~g}$, vitamin $\mathrm{B}_{6}: 3$ $\mathrm{g}$, vitamin $\mathrm{B}_{12}: 0.0012 \mu \mathrm{g}$, pantothenic acid: $12 \mathrm{~g}$, niacin: $25 \mathrm{~g}$, folic acid: $800 \mathrm{mg}$, biotin: $60 \mathrm{mg}$, selenium: $0.25 \mathrm{~g}$ per kg ${ }^{2}$ Copper: $20 \mathrm{~g}$, iron: $100 \mathrm{~g}$, manganese: $160 \mathrm{~g}$, cobalt: $2 \mathrm{~g}$, iodine: $2 \mathrm{~g}$, zinc $100 \mathrm{~g}$ per kg 
Table 2 Composition of experimental rations that vary in level of phytate and in the amount of calcium and phosphorus for feeding broilers during the grower phase

\begin{tabular}{|c|c|c|c|c|c|c|}
\hline \multirow{2}{*}{ Ingredients $\left(\mathrm{g} \mathrm{kg}^{-1}\right)$} & \multicolumn{2}{|c|}{$\mathrm{HP}$} & \multicolumn{2}{|c|}{ MP } & \multicolumn{2}{|c|}{ LP } \\
\hline & $\mathrm{PC}$ & $\mathrm{NC}$ & PC & $\mathrm{NC}$ & PC & $\mathrm{NC}$ \\
\hline Corn & 599.0 & 613.4 & 629.3 & 644.0 & 662.0 & 676.5 \\
\hline Soybean meal (45\%) & 261.1 & 258.6 & 211.9 & 209.2 & 229.6 & 227.0 \\
\hline Gluten feed meal & 35.0 & 35.0 & 28.0 & 28.0 & 18.0 & 18.0 \\
\hline Wheat bran & 35.0 & 35.0 & 35.0 & 35.0 & - & - \\
\hline Soybean oil & 31.9 & 26.9 & 23.5 & 18.5 & 17.2 & 12.2 \\
\hline Feather meal & - & - & 10.0 & 10.0 & 10.0 & 10.0 \\
\hline Poultry by-product meal & - & - & 28.0 & 28.0 & 30.0 & 30.0 \\
\hline Monocalcium phosphate & 11.99 & 4.32 & 7.67 & - & 7.67 & - \\
\hline Limestone & 10.67 & 10.82 & 9.55 & 9.71 & 9.29 & 9.45 \\
\hline Lysine (51.7\%) & 4.83 & 4.90 & 5.81 & 5.90 & 5.22 & 5.29 \\
\hline Salt & 3.52 & 3.51 & 3.21 & 3.21 & 3.19 & 3.18 \\
\hline DL-Methionine (98\%) & 2.28 & 2.27 & 2.42 & 2.40 & 2.48 & 2.47 \\
\hline Vitamin premix & 1.20 & 1.20 & 1.20 & 1.20 & 1.20 & 1.20 \\
\hline Na bicarbonate & 1.00 & 1.00 & 1.00 & 1.00 & 1.00 & 1.00 \\
\hline L-Threonine (99\%) & 0.54 & 0.54 & 0.78 & 0.78 & 0.70 & 0.70 \\
\hline Choline chloride & 0.55 & 0.55 & 0.55 & 0.55 & 0.55 & 0.55 \\
\hline Salinomycin $12 \%$ & 0.55 & 0.55 & 0.55 & 0.55 & 0.55 & 0.55 \\
\hline L-Valine (99\%) & 0.18 & 0.18 & 0.40 & 0.41 & 0.36 & 0.36 \\
\hline Mineral premix ${ }^{2}$ & 0.50 & 0.50 & 0.50 & 0.50 & 0.50 & 0.50 \\
\hline L-Isoleucine (99\%) & - & - & 0.30 & 0.32 & 0.23 & 0.24 \\
\hline Avilamycin $10 \%$ & 0.05 & 0.05 & 0.05 & 0.05 & 0.05 & 0.05 \\
\hline L-Tryptophan & - & - & 0.13 & 0.14 & 0.10 & 0.11 \\
\hline Inert (sand) & - & 0.40 & - & 0.40 & - & 0.40 \\
\hline
\end{tabular}

PC: positive control; NC: negative control; HP: high phytate; MP: medium phytate; LP: low phytate.

${ }^{1}$ Vitamin $A: 2.7 \mathrm{~g}$, vitamin $\mathrm{D}_{3}: 0.75 \mathrm{~g}$, vitamin $\mathrm{E}: 0.06 \mathrm{~g}$, vitamin $\mathrm{K}_{3}: 2.5 \mathrm{~g}$, vitamin $\mathrm{B}_{1}: 1.5 \mathrm{mg}$, vitamin $\mathrm{B}_{2}: 6 \mathrm{~g}$, vitamin $\mathrm{B}_{6}: 3$ $\mathrm{g}$, vitamin $\mathrm{B}_{12}: 0.0012 \mu \mathrm{g}$, pantothenic acid: $12 \mathrm{~g}$, niacin: $25 \mathrm{~g}$, folic acid: $800 \mathrm{mg}$, biotin: $60 \mathrm{mg}$, selenium: $0.25 \mathrm{~g}$ per kg

${ }^{2}$ Copper: $20 \mathrm{~g}$, iron: $100 \mathrm{~g}$, manganese: $160 \mathrm{~g}$, cobalt: $2 \mathrm{~g}$, iodine: $2 \mathrm{~g}$, zinc $100 \mathrm{~g}$ per kg

Three levels of phytate, namely HP, MP and LP, were cross-classified with a PC diet, NC and three diets in which the NC diet was supplemented with 500,1000 or 1500 FTU $\mathrm{kg}^{-1}$ of phytase. One FTU is defined as the quantity of enzyme necessary to release one $\mu$ mole of inorganic phosphate per minute from $5.0 \mathrm{mM}$ sodium phytate at $\mathrm{pH} 5.5$ and $37^{\circ} \mathrm{C}$. The phytase enzyme (Qingdao KDN Biotech Co. Ltd., Qingdao, China) was added at the rates of 100,200 , and $300 \mathrm{mg} \mathrm{kg}^{-1}$ in formulating the diets. The HP diet contained no animal by-product meal. The MP diet contained a reduced amount of soybean meal and soybean oil, and was supplemented with either meat and bone meal during the starter phase or feather meal during the grower phase and poultry by-product meal. The LP diet had a similar amount of soybean meal to the MP diet, with the soybean oil content being further reduced, wheat bran removed, and the animal by-product meals remaining at the same levels. The PC diet was formulated to meet the nutritional requirements of the broilers. The NC diet had to have the same energy and protein content as the PC diet, but with $0.15 \%$ less $\mathrm{Ca}$ and $0.15 \%$ less $\mathrm{P}$. The diets were formulated according to feed composition and nutritional requirements for broilers (Rostagno et al., 2017). All diets were fed in mash form, and birds had ad libitum access to feed and water.

The starter diets (Table 3 ) all provided $12.56 \mathrm{MJ}$ of metabolizable energy and $213.9 \mathrm{~g}$ of crude protein per $\mathrm{kg}$. Likewise, the grower diets (Table 4) provided $12.98 \mathrm{MJ}$ of metabolizable energy and $194.0 \mathrm{~g}$ of crude protein per $\mathrm{kg}$. 
Table 3 Nutritional content of the experimental rations that vary in level of phytate and in the amount of calcium and phosphorus for feeding broilers during the starter phase

\begin{tabular}{|c|c|c|c|c|c|c|}
\hline \multirow{2}{*}{ Nutrient } & \multicolumn{2}{|c|}{$\mathrm{HP}$} & \multicolumn{2}{|c|}{ MP } & \multicolumn{2}{|c|}{ LP } \\
\hline & PC & NC & PC & NC & PC & NC \\
\hline Metabolizable energy, $\mathrm{MJ} \mathrm{kg}^{-1}$ & 12.56 & 12.56 & 12.56 & 12.56 & 12.56 & 12.56 \\
\hline Crude protein, $\mathrm{g} \mathrm{kg}^{-1}$ & 213.9 & 213.9 & 213.9 & 213.9 & 213.9 & 213.9 \\
\hline Calcium, $\mathrm{g} \mathrm{kg}^{-1}$ & 8.56 & 7.06 & 8.56 & 7.06 & 8.56 & 7.06 \\
\hline Total phosphorus, $\mathrm{g} \mathrm{kg}^{-1}$ & 6.49 & 5.08 & 6.53 & 5.13 & 6.45 & 5.01 \\
\hline Available phosphorus, $\mathrm{g} \mathrm{kg}^{-1}$ & 4.20 & 2.70 & 4.17 & 2.67 & 4.17 & 2.67 \\
\hline Phytate phosphorus, $\mathrm{g} \mathrm{kg}^{-1}$ & 2.44 & 2.46 & 2.33 & 2.35 & 2.22 & 2.24 \\
\hline Sodium, $\mathrm{g} \mathrm{kg}^{-1}$ & 1.90 & 1.90 & 1.90 & 1.90 & 1.90 & 1.90 \\
\hline Digestible lysine, $\mathrm{g} \mathrm{kg}^{-1}$ & 12.26 & 12.26 & 12.26 & 12.26 & 12.26 & 12.26 \\
\hline Digestible methionine + cysteine, $\mathrm{g} \mathrm{kg}^{-1}$ & 8.84 & 8.84 & 8.84 & 8.84 & 8.84 & 8.84 \\
\hline Digestible threonine, $\mathrm{g} \mathrm{kg}^{-1}$ & 7.97 & 7.97 & 7.97 & 7.97 & 7.97 & 7.97 \\
\hline Digestible valine, $\mathrm{g} \mathrm{kg}^{-1}$ & 9.44 & 9.44 & 9.44 & 9.44 & 9.44 & 9.44 \\
\hline Digestible isoleucine, $\mathrm{g} \mathrm{kg}^{-1}$ & 8.33 & 8.32 & 8.22 & 8.22 & 8.22 & 8.22 \\
\hline
\end{tabular}

PC: positive control; NC: negative control; HP: high phytate; MP: medium phytate; LP: low phytate

Table 4 Nutritional content of experimental rations that vary in level of phytate and in the amount of calcium and phosphorus for feeding broilers during grower phase

\begin{tabular}{|c|c|c|c|c|c|c|}
\hline \multirow{2}{*}{ Nutrient } & \multicolumn{2}{|c|}{ HP } & \multicolumn{2}{|c|}{ MP } & \multicolumn{2}{|c|}{ LP } \\
\hline & PC & NC & PC & NC & PC & NC \\
\hline Metabolizable energy, $\mathrm{MJ} \mathrm{kg}^{-1}$ & 12.98 & 12.98 & 12.98 & 12.98 & 12.98 & 12.98 \\
\hline Crude protein, $\mathrm{g} \mathrm{kg}^{-1}$ & 194.0 & 194.0 & 194.0 & 194.0 & 194.0 & 194.0 \\
\hline Calcium, $\mathrm{g} \mathrm{kg}^{-1}$ & 7.32 & 5.82 & 7.32 & 5.82 & 7.32 & 5.82 \\
\hline Total phosphorus, $\mathrm{g} \mathrm{kg}^{-1}$ & 5.69 & 4.29 & 5.60 & 4.19 & 5.46 & 4.05 \\
\hline Available phosphorus, $\mathrm{g} \mathrm{kg}^{-1}$ & 3.42 & 1.92 & 3.42 & 1.92 & 3.42 & 1.92 \\
\hline Phytate phosphorus, $\mathrm{g} \mathrm{kg}^{-1}$ & 2.39 & 2.41 & 2.25 & 2.27 & 2.11 & 2.13 \\
\hline Sodium, $\mathrm{g} \mathrm{kg}^{-1}$ & 1.85 & 1.85 & 1.85 & 1.85 & 1.85 & 1.85 \\
\hline Digestible lysine, $\mathrm{g} \mathrm{kg}^{-1}$ & 10.78 & 10.78 & 10.78 & 10.78 & 10.78 & 10.78 \\
\hline Digestible methionine + cysteine, $\mathrm{g} \mathrm{kg}^{-1}$ & 7.87 & 7.87 & 7.87 & 7.87 & 7.87 & 7.87 \\
\hline Digestible threonine, $\mathrm{g} \mathrm{kg}^{-1}$ & 7.01 & 7.01 & 7.01 & 7.01 & 7.01 & 7.01 \\
\hline Digestible valine, $\mathrm{g} \mathrm{kg}^{-1}$ & 8.41 & 8.41 & 8.41 & 8.41 & 8.41 & 8.41 \\
\hline Digestible isoleucine, $\mathrm{g} \mathrm{kg}^{-1}$ & 7.42 & 7.40 & 7.33 & 7.33 & 7.33 & 7.33 \\
\hline
\end{tabular}

PC: positive control; NC: negative control; HP: high phytate; MP: medium phytate; LP: low phytate

Weight gain (WG), feed intake (FI), and feed conversion ratio (FCR) were recorded from day 1 to day 42. Mean individual bird weight and FI were calculated, taking mortalities into consideration (Sakomura \& Rostagno, 2016).

At 42 days old, two birds per pen were randomly selected, fasted for six hours, and blood samples were collected via brachial puncture. Blood was coagulated and centrifuged at $1008 \mathrm{~g} \mathrm{rpm}$ for $10 \mathrm{~min}$ to obtain serum, which was stored at $-20^{\circ} \mathrm{C}$. To perform the analyses, serum was thawed at room temperature, centrifuged at $1008 \mathrm{~g}$ for $5 \mathrm{~min}$, and then $\mathrm{Ca}, \mathrm{P}$, and alkaline phosphatase (ALP) analyses were performed with a high-performance automatic spectrophotometer (Flexor EL 200, Elitech, Paris, France) with specific kits, calibrated with standards (Elical, Elitech, Paris, France). 
Evaluation of bone development was conducted at 42 days old. Two birds with mean group weights $( \pm$ $5 \%$ ) were weighed and euthanized by electronarcosis followed by exsanguination (Normative Resolution No. 37 of 15 February 2018, CONCEA). The legs were separated and deboned to obtain the tibia. After deboning, the left tibias were weighed to the nearest $\pm 0.0001 \mathrm{~g}$ and the length was determined with a digital calliper (accuracy of $0.01 \mathrm{~mm}$ ). The bone density was calculated by dividing the bone weight $(\mathrm{mg})$ by its length (mm), thus obtaining the Seedor Index (Seedor et al., 1991). After bone density had been determined, the tibia was stored individually at $-20 \stackrel{\circ}{C}$ for further analysis.

Bone-breaking strength (BS) was determined after the bone had been thawed at room temperature. The tibia were supported individually on the epiphysis regions. A force load of $200 \mathrm{kgf}$ at the speed of $5 \mathrm{~mm}$ $\mathrm{s}^{-1}$ was applied in the central area of each bone with the probe TA-TPB and a CT3 texture analyser (AMETEK Brookfield, Middleboro, Massachusetts, USA).

After BS was measured, the tibia was weighed on an analytical balance $( \pm 0.0001 \mathrm{~g})$ and its dry matter content was determined (AOAC, 1995). Samples were weighed, ashed overnight at $600{ }^{\circ} \mathrm{C}$ and weighed again (Hall et al., 2003, adapted). The percentage of tibia ash was calculated as the proportion of the dry pre-ashed tibia multiplied by 100 .

To determine the amount of $\mathrm{Ca}$ and $\mathrm{P}$ in the bones, the ashes were placed in a sand bath $\left(250{ }^{\circ} \mathrm{C}\right)$ in a solution of $\mathrm{HCl}(6 \mathrm{M})$ to solubilize the minerals. Calcium was measured with an atomic absorption apparatus (GBC-932AA) and phosphorus with a spectrophotometer (UV/VIS GBC-916).

To evaluate the incidence of tibial dyschondroplasia, the left tibia of $(n=105)$ 42-day old birds were decalcified with $50 \%$ formic acid and $20 \%$ sodium citrate (Fernandes et al., 2007). After decalcification, the bone was embedded in paraffin (Beçak \& Paulete, 1976). The sections were made with microtomes at five $\mu \mathrm{m}$ thickness and stained with haematoxylin-eosin to observe the epiphyseal disk area. For analysis of tibial epiphyseal cartilage slides, two distinct regions were considered, characterized by morphological appearance, namely growth plate (A1) and hypertrophic cartilage zone (A2). The images were measured with a computerized image analyser PROPLUS IMAGE 4.1.

The left tibias $(n=105)$ were used to determine radiographic bone densitometry (bone mineral density), which was performed at the Dentistry Clinic of the University Hospital of Cascavel. The tibiotarsus was utilized to determine the optical densitometry in radiographic images compared with an aluminium scale with 10 degrees for $1 \mathrm{~mm}$ (penetrometer). The bones were radiographed with a dental X-ray machine (Orthopantomograph OP 300, Instrumentarium Dental, Tuusula, Finland) at $85 \mathrm{kVp}, 6.3 \mathrm{~mA}$, and 10 seconds exposure time. The digital images were analysed with Adobe Photoshop CS6. Five areas of each penetrometer degree $(1-5 \mathrm{~mm})$ were analysed, and the equation was calculated from these values. Six regions of each bone were performed, and the value obtained was applied in the equation to determine the value of bone mineral density expressed as millimetres of aluminium $(\mathrm{mm} \mathrm{Al})$. Higher values indicated greater radiopacity and greater bone density.

At the end of the experiment, four birds per pen were selected to evaluate carcass yield and cuts, which included wings, legs, breast, breast fillet, and abdominal fat (removed from around the cloaca and gizzard).

All data were analysed with SAS version 9.1 (SAS Institute Inc., Cary, North Carolina, USA). An analysis of variance and subsequent polynomial regression between levels of inclusion of the enzyme was performed, excluding the PC treatment. Also, Dunnett's test was performed at the $5 \%$ probability level to compare the PC treatment with the other treatments. Tukey`s test was performed to compare the means of each phytate content.

\section{Results and Discussion}

There were no interactions $(P>0.05)$ between phytase supplementation and phytate content on broiler performance (Table 5). Hence, the means for all 15 dietary treatments are not presented. No effects $(P>0.05)$ were observed for enzyme supplementation and phytate content on FI and FCR. However, WG showed a quadratic response $(P<0.05)$ as the level of phytase inclusion increased from 0 to $1500 \mathrm{FTU} \mathrm{kg}^{-1}$, with the maximum response being calculated at $952 \mathrm{FTU} \mathrm{kg}^{-1}$. Broilers that received NC exhibited the lowest WG, which was $3.19 \%$ lower than PC and significantly different from the WG of broilers that received NC + $1000 \mathrm{FTU} \mathrm{kg}{ }^{-1}$ diets, which was $2.84 \%$ higher than PC. The regression equation describing the response in WG to supplemental phytase $(\mathrm{X})$ was:

$$
W G=2702.317564+0.422784 X-0.000222 X^{2}
$$

This equation explained $37 \%$ of the variation in WG and had an estimated maximum response of 2904 $\mathrm{g}$ with $952 \mathrm{FTU} \mathrm{kg}^{-1}$ of phytase supplementation. 
Table 5 Effect of dietary phytate and phytase on broiler performance at 42 days old

\begin{tabular}{lccc}
\hline Treatments & Feed intake, $g$ & Weight gain, g & Feed conversion ratio \\
\hline High phytate & 4400 & 2850 & 1.545 \\
Medium phytate & 4320 & 2800 & 1.547 \\
Low phytate & 4270 & 2820 & 1.518 \\
Positive control (PC) & 4300 & 2820 & 1.527 \\
Negative control (NC) & 4260 & 2730 & 1.563 \\
NC + 500 FTU kg-1 & 4390 & 2860 & 1.553 \\
NC + 1000 FTU kg & 4340 & 2900 & 1.498 \\
NC + 1500 FTU kg & 4340 & 2840 & 1.530 \\
CV (\%) & 4.76 & 3.98 & 4.65 \\
SE & 0.020 & 0.011 & 0.007 \\
$P$-values & & & \\
$\quad$ Phytate level & 0.066 & 0.430 & 0.399 \\
Phytase enzyme level & 0.226 & $<0.001$ & 0.087 \\
Interaction & 0.234 & 0.553 & 0.138 \\
Regression on enzyme level & 0.259 & $<0.001$ & 0.534 \\
\hline
\end{tabular}

There were no interactions $(P>0.05)$ between phytase supplementation and levels of dietary phytate based on bone characteristics (Table 6).

Table 6 Effect of dietary phytate and phytase on characteristics of tibia from broilers at 42 days old

\begin{tabular}{lrrrrrrr}
\hline Treatments & $\mathrm{SI}$ & $\begin{array}{c}\mathrm{BS}, \mathrm{kgf}^{-1} \\
\mathrm{~mm}^{-1}\end{array}$ & $\begin{array}{c}\mathrm{DM}, \mathrm{gkg}^{-1} \\
\mathrm{BA}, \mathrm{g} \mathrm{kg}^{-1}\end{array}$ & $\mathrm{~A} 1, \mathrm{~mm}^{2}$ & $\mathrm{~A} 2, \mathrm{~mm}^{2}$ & $\mathrm{MBD}$ \\
\hline High phytate & 143.54 & 30.09 & 479.2 & 418.2 & 24.25 & $57.77^{\mathrm{ab}}$ & 3.79 \\
$\quad$ Medium phytate & 144.65 & 30.98 & 479.1 & 404.9 & 23.74 & $54.10^{\mathrm{b}}$ & 3.82 \\
$\quad$ Low phytate & 145.46 & 31.35 & 487.2 & 412.4 & 23.72 & $60.42^{\mathrm{a}}$ & 3.88 \\
$\quad$ Positive control & 144.60 & 32.06 & 489.5 & 415.6 & 23.90 & 56.23 & 3.85 \\
$\quad$ Negative control (NC) & 145.53 & 28.26 & 465.4 & 407.5 & 23.23 & 57.28 & 3.87 \\
$\quad$ NC + 500 FTU kg & 145.02 & 30.64 & 479.9 & 410.5 & 22.89 & 61.69 & 3.90 \\
$\quad$ NC + 1000 FTU kg & 146.36 & 33.06 & 492.8 & 410.7 & 23.94 & 56.19 & 3.76 \\
$\quad$ NC + 1500 FTU kg & 141.21 & 31.27 & 487.2 & 418.1 & 25.72 & 55.53 & 3.76 \\
CV (\%) & 7.27 & 15.77 & 5.04 & 6.04 & 14.85 & 19.17 & 8.19 \\
SE & 1.04 & 1.04 & 0.24 & 0.25 & 0.36 & 1.08 & 0.03 \\
$P$-values & & & & & & & \\
$\quad$ Phytate level & 0.786 & 0.556 & 0.597 & 0.136 & 0.704 & 0.048 & 0.522 \\
$\quad$ Phytase enzyme level & 0.417 & 0.009 & 0.003 & 0.560 & 0.080 & 0.346 & 0.567 \\
$\quad$ Interaction & 0.905 & 0.849 & 0.112 & 0.362 & 0.051 & 0.164 & 0.730 \\
$\quad$ Regression on enzyme level & 0.304 & 0.031 & 0.462 & 0.395 & 0.138 & 0.280 & 0.443
\end{tabular}

SI: Seedor index, BS: breaking strength, DM: dry matter, BA: bone ash, A1: area of the growth plate, A2: area of the hypertrophic cartilage zone, MBD: mineral bone density 
Seedor index (SI), bone ash (BA), growth plate (A1) and MBD were not influenced $(P>0.05)$ by enzyme supplementation and phytate content. Bone breaking strength had a quadratic response to phytase supplementation $(P<0.05)$. The equation describing that response was:

$$
B S=28.04408333+0.00855555 X-0.00000418 X^{2}
$$

where: $\mathrm{X}=$ the level of phytase supplementation.

This equation explained $13 \%$ of the variation in BS and had an estimated maximum response of 32.42 $\mathrm{kg}$ force $\mathrm{mm}^{-1}$ with $1023.4 \mathrm{FTU} \mathrm{kg}{ }^{-1}$ of phytase supplementation. Broilers that received the NC treatment had the lowest BS, which was $11.85 \%$ lower than PC, and lowest bone DM content, which was $4.92 \%$ lower than PC. The area of the hypertrophic cartilage zone (A2) was higher in broilers receiving LP diets compared with broilers fed the MP diets $(P<0.05)$.

No significant $(P>0.05)$ interaction or isolate effect was found in ALP (Table 7). There was an interaction $(P<0.05)$ between phytase supplementation and phytate content on blood $\mathrm{Ca}$ and $\mathrm{P}$. Birds fed diets with HP content and receiving the NC and NC $+500 \mathrm{FTU} \mathrm{kg}^{-1}$ had a higher concentration of serum $\mathrm{Ca}$ and $\mathrm{P}(P<0.05)$ compared with birds fed LP diets. Birds fed diets with NC $+1500 \mathrm{FTU} \mathrm{kg}^{-1}$ and HP had a lower concentration $(P<0.05)$ of serum $\mathrm{Ca}$ compared with birds fed other diets. Serum $\mathrm{P}$ had a quadratic response to phytase supplementation $(P<0.05)$. The equation describing that response was:

$$
P=4.723000000+0.002319095 X-0.000001174 X^{2}
$$

where: $\mathrm{X}=$ the level of phytase supplementation.

This equation explained $20 \%$ of the variation in serum $\mathrm{P}$ and had an estimated maximum response of $5.9 \mathrm{mg} \mathrm{dl}^{-1}$ with $987.7 \mathrm{FTU} \mathrm{kg}{ }^{-1}$ of phytase supplementation. A significant effect $(P<0.05)$ was observed in which the $\mathrm{Ca}$ content of the tibia showed a progressive increase with the level of phytase supplementation. Broilers that received HP diets also had a higher tibia Ca content than MP $(P<0.05)$. For $\mathrm{P}$, only birds in the $\mathrm{NC}$ treatment differed $(P<0.05)$ from those in PC.

\begin{tabular}{|c|c|c|c|c|c|}
\hline \multirow{2}{*}{ Treatments } & \multicolumn{3}{|c|}{ Serum } & \multicolumn{2}{|c|}{ Bone } \\
\hline & $\mathrm{Ca}, \mathrm{mg} \mathrm{dl}^{-1}$ & $\mathrm{P}, \mathrm{mg} \mathrm{dl}^{-1}$ & $A L P, U^{-1}$ & $\mathrm{Ca}, \mathrm{g} \mathrm{kg}^{-1}$ & $\mathrm{P}, \mathrm{g} \mathrm{kg}^{-1}$ \\
\hline High phytate & $9.32^{\mathrm{a}}$ & $5.96^{\mathrm{a}}$ & 186.88 & $192.5^{\mathrm{a}}$ & 98.7 \\
\hline Medium phytate & $9.18^{\mathrm{ab}}$ & $5.34^{\mathrm{b}}$ & 190.11 & $176.1^{b}$ & 102.3 \\
\hline Low phytate & $8.92^{b}$ & $5.36^{\mathrm{b}}$ & 205.38 & $184.8^{\mathrm{ab}}$ & 97.2 \\
\hline Positive control & 9.54 & 5.95 & 206.17 & 194.0 & 101.9 \\
\hline Negative control (NC) & 9.16 & $4.99^{*}$ & 207.33 & 172.4 & $93.3^{*}$ \\
\hline $\mathrm{NC}+500 \mathrm{FTU} \mathrm{kg}^{-1}$ & 9.39 & 5.80 & 203.93 & 180.9 & 96.8 \\
\hline $\mathrm{NC}+1000 \mathrm{FTU} \mathrm{kg}^{-1}$ & 8.98 & 5.66 & 180.93 & 180.1 & 97.9 \\
\hline $\mathrm{NC}+1500 \mathrm{FTU} \mathrm{kg}^{-1}$ & 9.03 & 5.63 & 187.07 & 194.4 & 107.9 \\
\hline CV (\%) & 9.09 & 13.05 & 30.35 & 101.4 & 106.1 \\
\hline SE & 0.08 & 0.07 & 5.91 & 0.19 & 0.11 \\
\hline \multicolumn{6}{|l|}{$P$-values } \\
\hline Phytate level & 0.047 & $<0.001$ & 0.393 & $<0.001$ & 0.050 \\
\hline Phytase enzyme level & 0.128 & $<0.001$ & 0.468 & $<0.001$ & $<0.001$ \\
\hline Interaction & $<0.001$ & $<0.001$ & 0.160 & 0.376 & 0.031 \\
\hline Regression on enzyme level & 0.534 & $0.003(\mathrm{Q})$ & 0.322 & 0.438 & 0.153 \\
\hline
\end{tabular}

Table 7 Effect of dietary phytate and phytase on serum and bone mineral contents of broilers at 42 days old

Ca: calcium, P: phosphorus, ALP: alkaline phosphatase 
The interaction effect between levels of phytate and phytase on serum calcium, serum phosphorus and the phosphorus content of the tibia are detailed in Table 8. Two quadratic regression equations were calculated that described the response in serum $\mathrm{P}$ to supplementation with the phytase enzyme $(X)$ at each level of dietary phytate, as indicated by the subscripted dependent variables. These equations were:

$$
\begin{gathered}
P_{M P}=4.194321429+0.003021500 X-0.000001386 X^{2}, \text { and } \\
P_{L P}=3.443285714+0.004506571 X-0.000002029 X^{2} .
\end{gathered}
$$

These equations described $50 \%$ and $90 \%$ of the variation in serum phosphorus that is attributable to the phytase level at the various levels of dietary phytate. The predicted maxima for these equations were 5.84 and $9.95 \mathrm{mg} \mathrm{dl}^{-1}$, which occurred at phytase supplementation levels of 1090.0 and $1110.5 \mathrm{FTU}$, respectively. A third quadratic equation described the response on $\mathrm{P}$ content of the tibia in birds fed LP. That equation was:

$$
P_{L P}=9.302970297-0.001876040 X+0.000001997 X^{2} .
$$

It explained $54 \%$ of the variation in the phosphorus content of the tibia, with an estimated minimum of $8.86 \mathrm{~g} \mathrm{~kg}^{-1}$ occurring at a supplementation of level of 469.7 FTU.

Table 8 Interaction effects between phytate level and phytase supplementation level on serum calcium and phosphorus and on the phosphorus content of bone from 42-day-old broilers

\begin{tabular}{lrrrrr}
\hline Serum calcium, $\mathrm{mg} \mathrm{dl}^{-1}$ & \multicolumn{5}{c}{ Treatments } \\
\cline { 2 - 6 } & $\mathrm{NC}$ & $\mathrm{NC}+500$ & $\mathrm{NC}+1000$ & $\mathrm{NC}+1500$ & $P$-value \\
\hline High phytate & $10.14^{\mathrm{a}}$ & $10.27^{\mathrm{a}}$ & 8.48 & $8.39^{\mathrm{b}}$ & 0.128 \\
$\quad$ Medium phytate & $8.67^{\mathrm{b}}$ & $9.25^{\mathrm{ab}}$ & 9.34 & $9.45^{\mathrm{a}}$ & 0.098 \\
$\quad$ Low phytate & $8.67^{\mathrm{b}}$ & $8.64^{\mathrm{b}}$ & 9.12 & $9.25^{\mathrm{a}}$ & 0.140 \\
Serum phosphorus, mg dl & & & & & \\
$\quad$ High phytate & & & & & \\
$\quad$ Medium phytate & $6.26^{\mathrm{a}}$ & $6.61^{\mathrm{a}}$ & 5.46 & 5.57 & 0.611 \\
$\quad$ Low phytate & $4.37^{\mathrm{a}}$ & $5.47^{\mathrm{b}}$ & 5.72 & 5.65 & 0.001 \\
Bone phosphorus, g kg-1 & $3.70^{\mathrm{b}}$ & $5.32^{\mathrm{b}}$ & 5.46 & 5.68 & $<0.001$ \\
$\quad$ High phytate & & & & & \\
$\quad$ Medium phytate & 9.02 & $9.96^{\mathrm{b}}$ & 9.17 & 10.73 & 0.070 \\
$\quad$ Low phytate & 9.56 & $10.35^{\mathrm{a}}$ & 10.46 & 10.77 & 0.060 \\
& 9.42 & $8.58^{\mathrm{c}}$ & 9.72 & 10.89 & 0.008
\end{tabular}

${ }^{1}$ Probability levels for the regression on level of phytase enzyme

${ }_{a, b, c}$ At each level of phytase supplementation, the values with a common superscript were not different with a probability $P=0.05$, by Tukey's test

Phytase level and phytate content did not influence $(P>0.05)$ carcass yield and cuts of broiler chickens at 42 days old (Table 9 ). Only the abdominal fat of birds that received the NC treatment was lower $(P<0.05)$ compared with PC treatment. 
Table 9 Effect of dietary phytate and phytase on the yields (\%) of carcass and cuts from broilers at 42 days old

\begin{tabular}{lcccccc}
\hline Treatments & Carcass & Wing & Whole leg & Breast & $\begin{array}{c}\text { Breast } \\
\text { fillet }\end{array}$ & $\begin{array}{c}\text { Abdominal } \\
\text { fat }\end{array}$ \\
\hline High phytate & & & & & & \\
$\quad$ Medium phytate & 70.65 & 10.34 & 29.27 & 40.59 & 35.43 & 1.93 \\
$\quad$ Low phytate & 70.80 & 10.36 & 28.86 & 41.18 & 35.84 & 1.87 \\
$\quad$ Positive control & 70.58 & 10.53 & 28.84 & 40.32 & 35.02 & 1.94 \\
$\quad$ Negative control (NC) & 70.84 & 10.24 & 29.01 & 39.83 & 34.45 & 2.11 \\
$\quad$ NC + 500 FTU kg & 70.58 & 10.64 & 28.56 & 41.03 & 35.72 & 1.73 \\
$\quad$ NC + 1000 FTU kg- & 70.46 & 10.35 & 29.11 & 40.83 & 35.33 & 1.97 \\
$\quad$ NC + 1500 FTU kg & 70.75 & 10.45 & 29.38 & 39.94 & 35.16 & 1.96 \\
CV (\%) & 70.94 & 10.19 & 29.27 & 40.97 & 35.50 & 2.05 \\
SE & 1.48 & 5.81 & 4.36 & 3.97 & 5.69 & 18.63 \\
$P$-values & 0.104 & 0.06 & 0.13 & 0.16 & 0.20 & 0.04 \\
$\quad$ Phytate level & & & & & & \\
$\quad$ Phytase enzyme level & 0.783 & 0.409 & 0.248 & 0.094 & 0.313 & 0.562 \\
$\quad$ Interaction & 0.559 & 0.100 & 0.197 & 0.062 & 0.817 & 0.012 \\
$\quad$ Regression on enzyme level & 0.960 & 0.702 & 0.556 & 0.428 & 0.776 & 0.051 \\
& 0.361 & 0.087 & 0.078 & 0.142 & 0.632 & 0.055 \\
\hline
\end{tabular}

Phytase supplementation increased phytate hydrolysis regardless of the phytate level, as indicated by the lack of phytate and phytase interaction. Higher doses of phytase than standard levels exerted an additive effect, which was also manifested in higher WG in broilers fed diets with $1000 \mathrm{FTU} \mathrm{kg}^{-1}$ phytase compared with the PC treatment.

The phytate content in the diets did not influence broiler performance variables, probably because the phytate concentration among diets was not large enough to show statistical differences. In a study by Morgan et al. (2016), there was an improvement in WG and FCR of broilers fed diets with highly degradable phytate compared with those fed diets with a lower level of degradable phytate, suggesting the occurrence of higher phytate hydrolysis in broilers fed the highly susceptible diet. The degradable phytate fraction was indicated to interfere in the digestion process and the higher level of hydrolysis of this fraction may be correlated with better performance. In phytate-rich diets, higher phytate hydrolysis occurs along the gastrointestinal tract, regardless of the presence or absence of phytase. Other factors, such as the ingredients of the diet, mineral and protein concentrations, phytate solubility, and gastrointestinal $\mathrm{pH}$, can influence phytate degradation (Morgan et al., 2016).

Improvement of bone parameters may be related to an increase in bone mineralization of diets supplemented with phytase, which could have led to higher availability of $P, C a$ and other minerals liberated from the phytate mineral complex (Singh et al., 2003; Gautier et al., 2018). Effects of phytase could be observed under increasing hydrolysis of phytate anti-nutritional effects on divalent cations, making the bone characteristics of phytase supplemented broilers similar to those receiving PC treatment. This positive action of phytase on bone characteristics was similar to the response observed on broiler WG. Better performance could be associated with adequate bone mineralization, which is essential to sustain the muscular development of the birds.

Bone growth and mineralization were less pronounced during the finisher phase, and this explains the lack of statistical difference among certain variables. The data demonstrated adequate bone development and integrity without disorders and the muscular, ligamentous and tendinous development was stabilized, parameters that depend on the bone state, which stabilizes as the birds grow (Amoroso et al., 2013).

Based on the interaction observed in blood samples, broilers fed diets with HP without phytase supplementation (NC) appeared to be trying to digest and absorb $\mathrm{Ca}$ and $\mathrm{P}$. This behaviour was evident from the increase of $\mathrm{Ca}$ and $\mathrm{P}$ in the blood.

As birds mature, there is a reduction in bone development, an increase in muscle development, and an accumulation of fat. Hence the bird's physiology responds to compensate for the lack of $\mathrm{Ca}$ and $\mathrm{P}$, thus increasing the circulating $\mathrm{Ca}$ and $\mathrm{P}$. This effect could be observed when phytase was added at $500 \mathrm{FTU} \mathrm{kg}^{-1}$ 
and from 1000 and $1500 \mathrm{FTU} \mathrm{kg}{ }^{-1}$ with a stabilization in high, medium and low phytate in the diet. In this case, phytase at higher doses was more effective in diets with HP.

Birds fed the NC and NC +500 and $1000 \mathrm{FTU} \mathrm{kg}^{-1}$ had a lower Ca deposition in the tibia compared with the PC, but with birds fed diets with $1500 \mathrm{FTU} \mathrm{kg}^{-1}$ of phytase had similar Ca deposition in tibia compared with the PC. However, the lower Ca content did not influence tibia BS and BA.

The improvement in bone mineralization observed in diets supplemented with phytase probably increased $\mathrm{P}$ or $\mathrm{Ca}$ utilization by liberating inorganic $\mathrm{P}$ and $\mathrm{Ca}$ from the phytate molecule in the digestive tract (Perney et al., 1993). The higher deposition of $\mathrm{Ca}$ and $\mathrm{P}$ in the bone was probably the main factor in the increase in other bone characteristics (SI, BS, DM, BA and MBD for example) as observed in the present study.

The activity of the enzyme ALP is used to evaluate bone dynamic and remodelling. In the growth phase of the animal, higher concentrations of this enzyme indicated an increase in the formation of the bone tissue. In the present study, the plasma concentration of ALP did not differ in the experimental treatments. The low levels of ALP observed when the broilers were at 42 days old were probably because the bones had already ossified.

The results of the carcass and cuts in the present study indicated that phytate levels were not sufficient to affect the growth of the broilers negatively. In the same way, when they examined the influence of phytic acid on birds fed control treatments containing 0.06 and $0.12 \%$ of phytic acid, Shibata et al. (2012) did not report differences in BW and part weights, such as wing, leg and breast. Also, phytase did not result in differences under these variables. These results agree with those of Singh et al. (2003) and Broch et al. (2018) in which carcass yield and cuts were not influenced by phytase supplementation.

Abdominal fat weight decreased significantly in broilers receiving NC treatment. This difference may be associated with the lower availability of nutrients and the reduced levels of soybean oil in NC diets, since dietary energy level can be modified to reduce body fat deposition (Fouad \& Senousey, 2014).

Phytate reduces the availability of minerals (such as $\mathrm{P}, \mathrm{Ca}$, zinc and copper), protein, amino acids, and energy in poultry diets (Saleh, 2017), which can lead to a reduction in poultry performance and bone characteristics. Exogenous phytase enzymes allow for greater flexibility during feed formulation by allowing the usage of a wider range of feed ingredients (Broch et al., 2018). There are limited studies in the literature that have investigated the influence of phytase in broiler diets with feed ingredients of animal origin, as most studies were based on vegetable diets.

Onyango \& Adeola (2009) evaluated the role of dietary phytate in the regulation of intestinal phytase and observed that the presence of phytate in the purified diet reduced the activity of duodenal brush border phytase and led to a reduction in performance variables. In their study, phytase supplementation partially reduced the antinutritional effects of phytate and they concluded that dietary phytates inhibited intestinal mucosa phytase non-competitively.

Although feed ingredients of animal origin do not contain phytate, most ingredients in poultry feed contain phytate. Therefore, it is essential to consider $\mathrm{P}$ availability and solubility in feed ingredients and phosphate sources, and interactions of minerals on P precipitation in the digesta (Hamdi et al., 2017).

Thus, it is necessary to investigate the impact of phytase on the performance of broilers offered diets containing various phytate concentrations. Also, phytases differ in their ability to hydrolyse phytate and this difference is dependent on the concentration and source of phytate in the diet and phytase characteristics (which may be related to the kinetics of individual phytases, $\mathrm{pH}$, and purity), energy, amino acid density, animal genetic and age (Onyango \& Adeola, 2009; Dos Santos et al., 2014; Cowieson et al., 2016).

\section{Conclusions}

Phytase supplementation produced a positive response in diets with reduced amounts of $\mathrm{Ca}$ and $\mathrm{P}$. For traits that responded favourably to phytase supplementation the optimal level in diets with reduced $\mathrm{Ca}$ and $\mathrm{P}$ was approximately at $1000 \mathrm{FTU} \mathrm{\textrm {kg } ^ { - 1 }}$. The overall effect of phytase could have been more pronounced if phytate concentration between diets had been greater. It should also be considered that mineral requirements for tibia development are reduced with age.

\section{Acknowledgments}

The authors acknowledge the Coordenação de Aperfeiçoamento de Pessoal de Nível Superior - Brazil (CAPES) for financial support for the PhD. scholarship for the first author - Finance Code 001.

\section{Authors' Contributions}

JB, VDLS, LW, EHC and GLST collected the data. JB, WJP, CE, GMP and RVN conducted the statistical analyses, collaborated in interpreting the results, wrote the initial draft of this manuscript, and finalized the manuscript. RVN, CE and VDLS developed the original hypothesis, designed the experiments, and collaborated in interpreting the results. The authors have read and approved the manuscript. 


\section{Conflict of Interest Declaration}

The authors declare there is no conflict of interest.

\section{References}

Amoroso, L., Baraldi, A.S.M., Barreiro, F.R., Pacheco, M.R., Alva, J.C.R., Soares, N.M., Pacheco, L.G. \& Melaré, M.C., 2013. Bone densitometry and calcium serum levels in chickens treated with filtered or unfiltered water. Braz. J. Poultry Sci. 15, 379-384. http://dx.doi.org/10.1590/S1516-635X2013000400013

Beçak, W. \& Paulete, J., 1976. Técnicas de citologia e histologia. Livros Técnicos e Científicos, Rio de Janeiro. 305 pp.

Broch, J., Nunes, R.V., Eyng, C., Pesti, G.M., de Souza, C., Sangalli, G.G., Fascina, V. \& Teixeira, L. 2018. High levels of dietary phytase improves broiler performance. Anim. Feed Sci. Technol. 244, 56-65. https://doi.org/10.1016/j.anifeedsci.2018.06.001

Cowieson, A.J., Ruckebusch, J.P., Knap, I., Guggenbuhl, P. \& Fru-Nji, F., 2016. Phytate-free nutrition: A new paradigm in monogastric animal production. Anim. Feed Sci. Technol. 222, 180-189. http://dx.doi.org/doi:10.1016/j.anifeedsci.2016.10.016

Dersjant-Li, Y., Awati, A., Schulze, H. \& Partridge, G., 2015. Phytase in non-ruminant animal nutrition: A critical review on phytase activities in the gastrointestinal tract and influencing factors. J. Sci. Food Agric. 95, 878-896. https://doi.org/10.1002/jsfa.6998

Dos Santos, T.T., Walk, C.L. \& Srinongkote, S., 2014. Influence of phytate level on broiler performance and the efficacy of 2 microbial phytases from 0 to 21 days of age. J. Appl. Poult. Res. 23, 181-187. https://doi.org/10.3382/japr.2013-00842

Fernandes, M.I., Gaio, J.E., Rosing, K.C., Oppermann, V.R. \& Rado, V.P., 2007. Microscopic qualitative evaluation of fixation time and decalcification media in rat maxillary periodontium. Braz. Oral Res. 21,134-139. http://dx.doi.org/10.1590/S1806-83242007000200007

Fouad, A.M. \& El-Senousey, H.K., 2014. Nutritional factors affecting abdominal fat deposition in poultry: A review. Asian Austral. J. Anim. 27, 1057-1068. http://dx.doi.org/10.5713/ajas.2013.13702

Gautier, A.E., Walk, C.L. \& Dilger, R.N., 2018. Effects of a high level of phytase on broiler performance, bone ash, phosphorus utilization, and phytate dephosphorylation to inositol. Poult. Sci. 97, 211-218. https://doi.org/10.3382/ps/pex291

Hall, L.E., Shirley, R.B., Bakalli, R.I., Aggrey, S.E., Pesti, G.M. \& Edwards Jr, H.M., 2003. Power of two methods for the estimation of bone ash of broilers. Poult. Sci. 82, 414-418. https://doi.org/10.1093/ps/82.3.414.

Hamdi, M., Solà Oriol, D., Franco Rosselló, R., Aligué I Alemany, R.M. \& Pérez, J.F., 2017. Comparison of how different feed phosphates affect performance, bone mineralization and phosphorus retention in broilers. Span. J. Agric. Res. 15, 1-10.

Leyva-Jimenez, H., Alsadwi, A.M., Gardner, K., Voltura, E. \& Bailey, C.A., 2019. Evaluation of high dietary phytase supplementation on performance, bone mineralization, and apparent ileal digestible energy of growing broilers. Poultry Science 9, 811-819.

Maenz, D.D., Engele-Schaan, C.M., Newkirk, R.W. \& Classen, H.L., 1999. The effect of minerals and mineral chelators on the formation of phytase-resistant and phytase-susceptible forms of phytic acid in solution and in a slurry of canola meal. Anim. Feed Sci. Technol. 81, 177-192. https://doi.org/10.1016/S0377-8401(99)00085-1.

Morgan, N.K., Walk, C.L., Bedford, M.R., Scholey, D.V. \& Burton, E.J., 2016. Effect of feeding broilers diets differing in susceptible phytate content. J. Anim. Nutri. 2, 33-39.

Onyango, E.M. \& Adeola, O., 2009. Dietary phytate (inositol hexaphosphate) regulates the activity of intestinal mucosa phytase. J. Anim. Physiol. Anim. Nut. 93: 639-646.

Pallauf, J. \& Rimbach, G., 1997. Nutritional significance of phytic acid and phytase. Arch. Anim. Nutr. 50, $301-319$. https://doi.org/10.1080/17450399709386141

Perney, K.M., Cantor, A.H., Straw, M.L. \& Herkelman, K.L., 1993. The effect of dietary phytase on growth performance and phosphorus utilization of broiler chicks. Poult. Sci. 72, 2106-2114. https://doi.org/10.3382/ps.0722106.

Ravindran, V., 1995 Phytases in poultry nutrition. An overview. Proc. Aust. Poult. Sci. Symp. Dept. Anim. Sci., Univ. Sydney. 7, 135-139.

Rostagno, H.S., Albino, L.F.T., Donzele, J.L., Gomes, P.C., Oliveira, R.F., Lopes, D.C., Ferreira, A.S. \& Barreto, S.L.T., 2017. Euclides. Tabelas brasileiras para aves e suínos: Composição de alimentos e exigências nutricionais. UFV, Departamento de Zootecnia, Viçosa.

Sakomura, N.K. \& Rostagno, H.S., 2016 Métodos de pesquisa em nutrição de monogástricos. 2nd edition. Jaboticabal: Funep.

Saleh A.A., 2017. Influence of Escherichia coli 6-phytase supplementation on performance and egg quality in hi-sex laying hens fed phosphorus deficient diets. Egypt. Poult. Sci. 37, 1105-1117.

Seedor, J.G., Quarraccio, H.H. \& Thompson, D.D., 1991. The biophosphonate alendronate (MK-217) inhibits bone loss due to ovariectomy in rats. Bone and Mineral Res. 6, 339-346. https://doi.org/10.1002/jbmr.5650060405.

Selle, P.H. \& Ravindran, V., 2007. Microbial phytase in poultry nutrition. Anim. Feed Sci. Technol. 135, 1-41. https://doi.org/10.1016/j.anifeedsci.2006.06.010.

Shibata, T., Yoneda, K., Araki, T. \& Nikki, T. 2012. Effect of phytic acid dietary level on growth performance and serum components in broiler chickens. Poult. Sci. 49, 111-115. https://doi.org/10.2141/jpsa.011112

Singh, P.K., Khatta, V.K., Thakur, R.S., Dey, S. \& Sangwan, M.L., 2003. Effects of phytase supplementation on the performance of broiler chickens fed maize and wheat based diets with different levels of non-phytate phosphorus. Asian-Australas. J. Anim. Sci. 11, 1642-1649. https://doi.org/10.5713/ajas.2003.1642. 
Walters, H.G., Coelho, M., Coufal, C.D. \& Lee, J.T., 2019. Effects of increasing phytase inclusion levels on broiler performance, nutrient digestibility, and bone mineralization in low-phosphorus diets. J. Appl. Poult. Res. 28, 1210-1225.

Wilkinson, S.J., Selle, P.H., Bedford, M.R. \& Cowieson, A.J., 2014. Separate feeding of calcium improves performance and ileal nutrient digestibility in broiler chicks. Anim. Prod. Sci. 54, 172-178

Zhang, W., Aggrey, S.E., Pesti, G.M., Edwards, Jr H.M. \& Bakalli, R.I., 2003. Genetics of phytate phosphorus bioavailability: Heritability and genetic correlations with growth and feed utilization traits in a random bred chicken population. Poult. Sci. 82, 1075-1079. https://doi.org/10.1093/ps/82.7.1075 